\title{
Low mortality rates of juvenile Pacific oysters in the German Wadden Sea are characteristic for invasive species: a reply to Beukema and Dekker
}

\author{
A. Schmidt $\cdot$ A. Wehrmann $\cdot$ S. Dittmann
}

Received: 24 July 2009 / Accepted: 25 July 2009 / Published online: 12 August 2009

(C) Springer-Verlag and AWI 2009

Many marine invertebrate species have decreasing mortality rates with age (Gosselin and Qian 1997), which raised a question (Beukema and Decker 2009) on the low mortality we reported for juvenile Pacific oysters in the East Frisian Wadden Sea (Schmidt et al. 2008). High fecundity is traditionally interpreted as a life history strategy to counteract high mortalities during early life stages, when unfavourable environmental conditions, competition or high predation can lead to a low recruitment success (Olafsson et al. 1994; Hunt and Mullineaux 2002). Beukema and Decker (2009) may therefore not be alone in doubting our values and we welcome the opportunity to clarify that such low juvenile mortalities are indeed a trait observable in the early stages of the invasion of marine invertebrates. Furthermore, as Gosselin and Qian (1997) also highlight, survival rates vary throughout the first year which may necessitate differentiation in future studies.

Prior to any evaluation of mortality, correct assessment of population parameters has to be assured. This can be confounded by sampling design and sampling errors, in particular where investigations are primarily field based, early life stages difficult to detect, or where high mobility of

Communicated by H.-D. Franke.

A. Schmidt · A. Wehrmann $(\square)$

Senckenberg Institute, Südstrand 40,

26382 Wilhelmshaven, Germany

e-mail: achim.wehrmann@senckenberg.de

\section{S. Dittmann}

School of Biological Sciences,

Flinders University of South Australia,

GPO Box 2100, Adelaide, SA 5001, Australia juveniles can lead to import and export of individuals (Gosselin and Qian 1997). In our study, the establishment of Pacific oysters (Crassostrea gigas) was studied along a $160 \mathrm{~km}$ stretch of intertidal coastline, with a dense net of sampling stations and a high rate of replication, yielding about 1,500 quadrate counts at each annual sampling occasion. All shell material found on the quadrates was visually examined for oyster spat in the field, carefully lifting the material off the sediment, cleaning it from attached sediment and checking all sides of the shells. Even oysters as small as $1 \mathrm{~mm}$ could be identified, as they differ in their colouration and structure from other epibionts (e.g. barnacles) or byssus threat attachments. We are thus confident that we accurately estimated the small oysters in the field. Retrieving material for cross-checks in the laboratory would not have been feasible as the overall goal of the monitoring scheme was to establish a long-term/large-scale data series on the population development of Pacific oysters in this region. Therefore, fixed GPS positions marked with bamboo stakes in the field were used to relocate the study sites. Beukema and Decker (2009) are concerned that morphological changes in mussel beds could account for variation in settlement substrates between years. Only well-established mussel beds with a stable topography were used for our surveys, documented through mussel monitoring (Herlyn and Millat 2004) and own assessment of the perimeter in 2003 and 2006 (Schmidt 2009; Wehrmann et al. 2009).

Beukema and Decker (2009) are further concerned about the allocation to cohorts based on size-frequency distributions, yet the program FISAT II allows for potential overlap, applying standard procedures to differentiate cohorts using Bhattacharya's method (Gayanilo et al. 2005).

To corroborate the mortality rate based on the annual monitoring, we calculated mortality for the first year from spatfall collectors deployed in the field (Schmidt 2009). 
Table 1 Comparison of mortality and survival rates recorded for various time intervals of juvenile bivalves and for settlement on different substrate

\begin{tabular}{|c|c|c|c|c|c|c|}
\hline Species & Timeframe & $Z\left(\right.$ days $\left.^{-1}\right)$ & $Z\left(\right.$ years $\left.^{-1}\right)$ & Survival $(\%)$ & Comment & References \\
\hline \multirow[t]{12}{*}{ Crassostrea gigas } & 89 days & $0.004 \pm 0.001$ & & 70 & $\begin{array}{l}\text { Ceramic tiles; } \\
\quad \text { August 2002-November } 2002\end{array}$ & Diederich (2006) \\
\hline & 314 days & 0.003 & 1.136 & 38 & $\begin{array}{l}\text { Shell collectors (oyster shells); } \\
\text { September 2004-August 2005, } \\
\text { near Mellum }\end{array}$ & This paper \\
\hline & 314 days & 0.002 & 0.612 & 59 & $\begin{array}{l}\text { Shell collectors (Mytilus shells); } \\
\text { September 2004-August 2005, } \\
\text { near Mellum }\end{array}$ & This paper \\
\hline & 314 days & 0.004 & 1.599 & 25 & $\begin{array}{l}\text { Shell collectors (Mya shells); } \\
\text { September 2004-August 2005, } \\
\text { near Mellum }\end{array}$ & This paper \\
\hline & 314 days & 0.003 & 1.026 & 41 & $\begin{array}{l}\text { Shell collectors (Cerastoderma shells); } \\
\text { September 2004-August 2005, } \\
\text { near Mellum }\end{array}$ & This paper \\
\hline & 86 days & $0.005 \pm 0.001$ & 1.914 & $63.7 \pm 7.1$ & $\begin{array}{l}\text { Shell collectors (oyster shells); } \\
\quad \text { November 2002-February } 2003\end{array}$ & Diederich (2006) \\
\hline & 224 days & $0.004 \pm 0.0004$ & 1.39 & $42.6 \pm 3.9$ & $\begin{array}{l}\text { Shell collectors (oyster shells); } \\
\text { November 2002-July } 2003\end{array}$ & Diederich (2006) \\
\hline & 213 days & 0.0003 & 0.104 & 94.1 & Oyster plots November 2001-May 2002 & Diederich (2006) \\
\hline & 578 days & 0.003 & 0.90 & 23.9 & Oyster plots November 2001-May 2003 & Diederich (2006) \\
\hline & 323/393 days & & $0.03 / 0.13$ & $97 / 88$ & $\begin{array}{l}\text { Based on annual surveys for population } \\
\text { dynamics May/July 2003-June 2004, } \\
\text { near Borkum/Juist }\end{array}$ & $\begin{array}{l}\text { Schmidt } \\
\quad \text { et al. (2008) }\end{array}$ \\
\hline & 19 months & 0.0003 & 0.107 & 84 & $\begin{array}{l}\text { River Exe crab tiles } \\
\quad \text { November 1991-June } 1993\end{array}$ & $\begin{array}{l}\text { Spencer } \\
\quad \text { et al. (1994) }\end{array}$ \\
\hline & 12 months & & & 96 & $\begin{array}{l}\text { River Teigh, naturally set oyster spat } \\
\text { on poches October 1991-October } 1992\end{array}$ & $\begin{array}{l}\text { Spencer } \\
\text { et al. (1994) }\end{array}$ \\
\hline \multirow[t]{2}{*}{$\begin{array}{l}\text { Ensis directus } \\
\quad \text { (cf. americanus) }\end{array}$} & 9 months & 0.0145 & 5.307 & 1 & Shallow water, high abundances & $\begin{array}{l}\text { Mühlenhardt-Siege } \\
\text { et al. (1983) }\end{array}$ \\
\hline & 9 months & 0.002 & 0.717 & 55 & Deeper water, low abundances & $\begin{array}{l}\text { Mühlenhardt-Siegel } \\
\text { et al. (1983) }\end{array}$ \\
\hline
\end{tabular}

Oyster spatfalls occurred around August in the northern and western Wadden Sea, thus recordings starting several months later could have missed initial mortality. Exact dates for spatfall were not available in most cases, therefore the timeframe of exposure is given in days or months instead of the age. In some cases recording preceded the spatfalls and actual sampling months are given in 'comments'

Collectors composed of numerous shells of various bivalve species suitable as initial settlement substrate were attached to the ground within a mussel bed near Mellum in April 2004 and the first collector set of each shell type retrieved on 30 September 2004, about 4-6 weeks after spatfall, and the second 1 year later on 10 August 2005. These shells were analysed in the laboratory for oyster spat, which was counted and measured under the microscope. The data provide us with an assessment of the population size at $\mathrm{N}_{1}$ and $\mathrm{N}_{0}$, and calculation of mortality using the same formula as in Schmidt et al. (2008).

The mortality rates obtained are comparable to those found on various collectors by Diederich (2006), and furthermore indicate different mortalities subject to the shell type used for settlement, with the lowest mortality recorded on blue mussel and the highest on Mya shells (Table 1). The comparison presented in Table 1, including further studies on early stages of the oysters invasion in the UK and of the American razor shell into the North Sea, reveals quite similar daily mortality rates. These low values vary with the duration of a study and the timing of the study period in relation to the spatfall, which leads to differences in the calculated annual mortality rates. Furthermore, the table shows that juvenile survival rates appear to decrease during the early years of invasion, and also differ between locations subject to site-specific commencement of invasion. A critical appraisal of the temporal study design is therefore needed prior to any evaluation of juvenile mortalities. The values compiled in Table 1 are further corroborated by the review of Gosselin and Qian (1997; Fig. 1) who showed that mortality decreases strongly in the time range of 120-180 days after settlement and remained low thereafter.

In our paper (Schmidt et al. 2008) we had stated clearly that the early mortality directly after settlement was not included in the calculation due to the sampling strategy 
used, and that we determined $\mathrm{N}_{0}$ about 6 months after settlement. Our values are comparatively low (Table 1), yet similar to mortality rates found during the early stages in the invasion of $C$. gigas in estuaries of the UK (Spencer et al. 1994) and by Diederich (2006) for oysters surviving the winter 2001-2002. Hence, the question is what could make high survival of juvenile invasive organisms possible.

Low juvenile mortality of recently introduced alien species, can be explained by various factors and processes. Predators may not have adapted to the new prey items available and competition may be negligible as densities are low. Furthermore, environmental conditions may be favourable. For example, high water temperatures $\left(>20^{\circ} \mathrm{C}\right)$ during spawning over summer could have reduced the energy expenditures of the larvae, leaving higher energy reserves for early juvenile stages (Gosselin and Qian 1997). Future research should address the relevance of high juvenile survival which could explain the exponential growth observed for many invasive species.

\section{References}

Beukema JJ, Decker R (2009) Extraordinarily low mortality rates reported in juvenile Pacific oysters in the German Wadden Sea: a comment. Helgol Mar Res (this volume)

Diederich S (2006) High survival and growth rates of introduced Pacific oysters may cause restrictions on habitat use by native mussels in the Wadden Sea. J Exp Mar Bio Ecol 328:211-227
Gayanilo FC, Sparre P, Pauly D (2005) FISAT II ver. 1.2.2. FAO, Rome

Gosselin LA, Qian P-Y (1997) Juvenile mortality in benthic marine invertebrates. Mar Ecol Prog Ser 146:265-282

Herlyn M, Millat G (2004) Wissenschaftliche Begleituntersuchungen zur Aufbauphase des Miesmuschelmanagements im Nationalpark "Niedersächsisches Wattenmeer". Abschlussbericht der Niedersächsischen Wattenmeerstiftung, Wilhelmshaven, Germany (unpublished data)

Hunt HL, Mullineaux LS (2002) The roles of predation and postlarval transport in recruitment of the soft shell clam (Mya arenaria). Limnol Oceanogr 47:151-164

Mühlenhardt-Siegel U, Dörjes J, von Cosel R (1983) Die amerikanische Schwertmuschel Ensis directus (Conrad) in der Deutschen Bucht: 2. Populationsdynamik. Senckenbergiana Marit 15(4-6):93-110

Olafsson EB, Peterson CH, Ambrose WG Jr (1994) Does recruitment limitation structure populations and communities of macro-invertebrates in marine soft sediments: the relative significance of pre- and post-settlement processes. Oceanogr Mar Biol Ann Rev 32:65-109

Schmidt A (2009) Gefährdungspotential der eulitoralen Miesmuschelbänke im Niedersächsischen Wattenmeer durch die Bioinvasion der Pazifischen Auster (Crassostrea gigas). Dissertation Thesis, Universität Bremen, Bremen, $165 \mathrm{pp}$

Schmidt A, Wehrmann A, Dittmann S (2008) Population dynamics of the invasive Pacific oyster Crassostrea gigas during the early stages of an outbreak in the Wadden Sea (Germany). Helgol Mar Res 62(4):367-376

Spencer BE, Edwards DB, Kaiser MJ, Richardson CA (1994) Spatfalls of the non-native Pacific oyster, Crassostrea gigas, in British waters. Aquatic Conserv Mar Freshw Ecosyst 4:203-217

Wehrmann A, Markert A, Esser W, Narkus S, Rabe K (2009) Management der Bioinvasion der Pazifischen Auster (Crassostrea gigas). Sachbericht der Niedersächsischen Wattenmeerstiftung, Wilhelmshaven, Germany, 198 pp (unpublished data) 